\title{
Factors Influencing the Dis-adoption of Moringa oleifera among Farming Households in Oyo State, Nigeria
}

\section{*OKE, DO; ORUMWENSE, LA; OLUGBIRE, OO; OLOBA, OG; AWOFADEJU, JOH; AKANBI, SF}

\author{
Forestry Research Institute of Nigeria, Ibadan Oyo State, Nigeria \\ *Corresponding Author Email: bunmioyetunji@yahoo.com
}

\begin{abstract}
This study was conducted to determine the factors influencing the disadoption of Moringa oleifera among farming households in Oyo State, Nigeria. Primary data were collected through the use of structured questionnaires for this study. Descriptive and quantitative techniques were used for the analysis of survey data. Result revealed that the level of disadoption of Moringa in the study area was high whereas those that are still cultivating moringa still realizes income it. Also, the respondents indicated that low return on investment on moringa oleifera, low demand of moringa oleifera products such as leaf and seeds, low sale of moringa products, inadequate processing equipment, and inadequate marketing channels and over hyped health benefit of moringa products were factors contributing to the disadoption of moringa oleifera cultivation. The study revealed that age, membership of farmers' association, non-farm income, and access to extension and involvement of the farmers in other agroforestry practices were significant factors influencing the disadoption of moringa in the study area. However, membership of farmers' association and access to extension services significantly influence the probability of disadoption of moringa cultivation negatively. This study therefore recommends that there should be further awareness on the benefits of moringa in order to increase demand for moringa and its product and that farmers should be encouraged to join Moringa farmers group in order to network with other farmers and to access information.
\end{abstract}

DOI:https://dx.doi.org/10.4314/jasem.v24i4.20

Copyright: Copyright $(C) 2020$ Oke et al. This is an open access article distributed under the Creative Commons Attribution License (CCL), which permits unrestricted use, distribution, and reproduction in any medium, provided the original work is properly cited.

Dates: Received: 10 February 2020; Revised: 14 March 2020; Accepted: 22 March 2020

Keywords: Dis-Adoption, Moringa oleifera, Probit and Oyo State.

Moringa oleifera(Lam.) is the most widely cultivated species of a monogeneric family, the Moringaceae, which is native to the sub-Himalayan tracts of India, Pakistan, Bangladesh and Afghanistan (Fahey, 2005). Moringa oleiferaalso known as the "tree for life" or "miracle tree" is found all over the world. Though native to Northern India, Pakistan and Bangladesh, it is also found in countries like China, Southeast Asia, Philippines, Africa, Mediterranean, West Indies, and parts of the Americas (Fahey, 2005). Moringa has an almost endless list of uses, from a multivitamin supplement to an agricultural strategy. In English it is commonly known as Horseradish tree, Drumstick tree, Never Die tree, West Indian Ben tree, and Radish tree. The local names are Ewe-Igbale or Idagbomonoye (Yoruba), Zogale (Hausa), Okwaoyibo or Oduduoyibo (Igbo). Moringa serves as a source of income to the rural inhabitants and therefore it is increasingly becoming an important source of livelihood for a number of people as several people have started nurseries to grow moringa in large quantities for sale within and outside the country. Peoples' reasons for planting and perceptions of benefits varied across the country. Some of the most common and most important reasons are the need for food; medicinal use; income generation and the diversity of other uses. Cultivation of this multiple-use species is an economic proposition unlike many slower growing and more habitat specific medicinal plant species. Moringa is already a popular tree for indigenous agroforestry in Nigeria and a multiple use species with similar potential in Africa. Meanwhile, cultivating the Moringa crop in an agroforestry practice as a perennial crop by small-scale farmers holds the promise of sustainable development. This is because, Moringa, like any other perennial crop will continue to produce for a number of years and it has the added advantage of not requiring that new sections of forest lands will be cleared every year (Animashaun, 2013). Perennial crop can also help restore nutrients to degraded soils by remaining productive for decades, bringing a steady stream of cash to needy farmers. A mixture of perennials and annuals can also work excellently well for small agricultural plots because such polycultural fields provide a diversified income (prices of many cash crops are notoriously volatile), as well as 
insurance if one crop fails (http://rainforests.mongabay.com). An added bonus of such agroforestry systems is that they maintain forest systems, soils, and biological diversity at a far higher level than do industrial agricultural techniques.

According to (Roger, 1995), the adoption of any innovation is the decision to make full use of such innovation as the best course of action available. This process composes of learning, deciding, and acting over a period of time. Individual adoption of an innovation is a decision-making process which goes through a number of mental stages before it is finally adopted. This process comprises of sequence of stages namely: Awareness stage, Interest stage, Evaluation stage, Trial stage and Adoption stage. In effect the adopters would have benefitted from the outcome as increased food security, health and economic status. Research findings and publications exist about Moringa oleifera awareness and adoption among Nigerians, their disadoption has not being fully ascertained. This is because after the introduction of an innovation its characteristics or attributes (relative advantage, compatibility, complexity, trial ability, evidence visibility, divisibility and accessibility) as perceived by the adopters can mare or promote its full adoption Tor et al., (2017).The adoption and diffusion of new products/technology has been studied extensively and comprehensively (Rogers,2003). Disadoption - how and why people volitionally stop using products/technology - by contrast, has received less and more situation-specific attention. Despite the obvious benefits and intensive extension efforts, we observed that adoption rate of moringa cultivation have generally been reduced. The average rate of disadoption (the proportion of households who have cultivated moringa but who no longer cultivate it) is high. This could be hinged on various socio-economic factors. These factors need to be well researched, identified and documented. Therefore, this study seeks to describe the socio-economic characteristics of the respondent, analyze the factors influencing the decision of farmers to discontinue the cultivation of moringa oleifera and the factors contributing to moringa dis-adoption among farmers within Oyo State.

\section{MATERIALS AND METHODS}

The study was carried out in Oyo state, South-West Nigeria. Thestudy area has heterogeneous population of Yoruba, Igbo and Hausa.Oyo state is located in the south west geopolitical zone of Nigeria. Oyostate consists of 33 local government areas. The state covers a total of 27,249 square kilometers of land mass and it is bounded in the south by Ogun state, in the north by
Kwara state, in the west partly by Ogun state and partly by Benin republic, and in the east by Osun state.

Multistage sampling techniques was employed in the selection of respondents. The first stage involved the selection of three (3) local government areas out of the thirty-three (33) local government areas of Oyo state using simple random technique. The local government that were selected include Akinyele, Iseyin and Oluyole local government. The second stage involvedthe purposive selection of three wards under each local government selected while the third stageinvolved the random selection of ten(12)farmers from each wardwhich makes the total sum of 108 respondents sampled but were able to retrieve 96 questionnaires.

Primary data were used for this study. The data were collected through the use of personally administered questionnaires. Data collected included age, household size, gender, income etc.

Both descriptive and quantitative techniques were used for the analysis of data gathered in this survey. Descriptive statistics such as frequency count and percentage were used in presenting the socioeconomic characteristics of respondents. Quantitatively the estimation of a probit model analysed the factors influencing the disadoption of moringa cultivation.

The probit model is used to explain the behaviour of a dichotomous dependent variable; it emerges from the Cummulative Distribution Function (CDF). It has been used to estimate factors affecting adoption and disadoption (Lagar and Pandey, 1999). The probit model, also known as the normit model, estimates the effects of $X i$ on the response probability, $P i=(Y I X)$ and assumes that individual farmers make decision based upon a utility maximization objective. It assumes an underlying normal distribution and it has an advantage of giving efficient, unbiased and normally distributed estimates. The chief difference between logit and probit is that logit has slightly flatter tails therefore, the conditional probability approaches zero or one at a lower rate in the logit than in the probit model (Gujarati, 2004).

The probit regression model was used to identify factors determining the disadoption of moringa cultivation by farmers in the study area. Following Dandedjrohoun et al. (2012) and DontsopNguezet et $a l$. , (2010) the model can be expressed as:

$\mathrm{Yi} *=\beta 0+\beta \mathrm{ijXij}+\mathrm{ei} 1$ 
Where: $Y i *$ is an underlying index reflecting the difference between the utility of adopting and not adopting; $\beta 0$ is the intercept, $\beta i j$ is a vector of parameters to be estimated; Xijdenotes the independent variables.

The probability of disdoption is determined by

$(Y i *=1 \mid x)=(\beta 0+\beta i j X i j) 2$

Where: $F$ is the function that ensures the likelihood of disdopting and is strictly between zero and one. Therefore, a farmer dis adopts moringa cultivation if $Y i *>0$ and otherwise $Y i * \leq 0$.

In this study the variables used are as follows:

$Y i *=$ Disadoption of moringa cultivation. (1 if Yes and 0 if No)

$\beta 0=$ Intercept

$\beta i=\mathrm{A}$ vector of parameter estimates

$X i=$ A vector of explanatory variables which include;

$X_{1}=$ Gender of the household head ( 1 if male, 0 if female)

$X_{2}=$ Age of the household head (years)

$X_{3}=$ Household size (number of household members)

$X_{4}=$ Membership of farmers' cooperative society (1 if

Yes and 0 otherwise)

$X_{5}=$ Membership of farmers' association (1 if Yes and 0 otherwise)

$X_{6}=$ Farming experience (years)

$X_{7}=$ Non-farm Income $(\mathrm{N}$ per year $)$

$X_{8}=$ Income from Moringa(N per year)

$X_{9}=$ Access to extension ( 1 if Yes and 0 otherwise)

$X_{10}=$ Involvement in other agroforestry practices (1 if

Yes and 0 otherwise)

$X_{11}=$ Distance of farm to the house $(\mathrm{km})$

$X_{12}=$ Distance of farm to the nearest expressway $(\mathrm{km})$

\section{RESULTS AND DISCUSSION}

The socio economic characteristics of the respondents were presented in Table 1. The result showed that $76 \%$ of the respondents were male and $24 \%$ were female. This implies that male respondents dominate moringa oleifera cultivation in the study area. This may be due to the fact that social/cultural factors which does not recognize women as household heads and as such do not recognize them as beneficiary of plots allocation but rather as labour used for farming activities. This finding agrees with Azeez et al.,(2013) that women were generally treated as part of labour available to the head of the household at a specific time such as during harvesting and processing.

The result from the age distribution revealed that $4.2 \%$ of the respondent are less than 30 years, $34.5 \%$ are within the ages of 30-50 years and the highest (61.5\%) of the respondent falls within the age range of 50 years and above. This shows that most of the respondents cultivating moringa oleifera are not in their active age. An indication that young people were not much involved in farming activities (Torimiro and Oluborode, 2006).

Table 1: Socio-economic characteristics of respondents

\begin{tabular}{|c|c|c|}
\hline Characteristics & Frequency & Percent \\
\hline \multicolumn{3}{|l|}{ Gender } \\
\hline Female & 23 & 24 \\
\hline Male & 73 & 76 \\
\hline \multicolumn{3}{|l|}{ Age Category } \\
\hline$\leq 30$ & 4 & 4.2 \\
\hline $31-40$ & 8 & 8.3 \\
\hline $41-50$ & 25 & 26.0 \\
\hline $51-60$ & 33 & 34.4 \\
\hline$>60$ & 26 & 27.1 \\
\hline \multicolumn{3}{|l|}{ Marital Status } \\
\hline Married & 88 & 91.7 \\
\hline Single & 06 & 6.3 \\
\hline Widowed & 2 & 2.1 \\
\hline \multicolumn{3}{|l|}{ Household Size Group } \\
\hline$\leq 4$ & 3 & 3.1 \\
\hline $5-8$ & 13 & 13.5 \\
\hline $9-12$ & 51 & 53.1 \\
\hline$>12$ & 29 & 30.2 \\
\hline \multicolumn{3}{|l|}{ Family Type } \\
\hline Polygamous & 75 & 78.1 \\
\hline Monogamous & 21 & 21.9 \\
\hline \multicolumn{3}{|l|}{ Religion } \\
\hline Christian & 35 & 36.5 \\
\hline Muslim & 60 & 62.5 \\
\hline Traditional & 1 & 1.0 \\
\hline Educational & \multirow{2}{*}{\multicolumn{2}{|c|}{ Qualification }} \\
\hline Attained & & \\
\hline No Formal Education & 11 & 11.5 \\
\hline Primary School & 25 & 27.1 \\
\hline Secondary School & 39 & 40.6 \\
\hline Tertiary School & 14 & 14.5 \\
\hline Vocational & 6 & 6.3 \\
\hline \multicolumn{3}{|l|}{ Main occupation } \\
\hline Farming & 65 & 67.7 \\
\hline Trading & 22 & 22.9 \\
\hline Civil Servant & 4 & 4.2 \\
\hline Artisan & 4 & 4.2 \\
\hline \multicolumn{3}{|c|}{ Farming Experience (Years) } \\
\hline Less than or equals 5 & 21 & 21.9 \\
\hline $6-10$ & 31 & 32.3 \\
\hline More than 10 & 44 & 45.8 \\
\hline \multicolumn{3}{|c|}{ Total Income/Annum( } \\
\hline$<50,000$ & 36 & 37.5 \\
\hline $50,000-100,000$ & 31 & 32.3 \\
\hline $101,000-150,000$ & 18 & 18.8 \\
\hline$>150,000$ & 11 & 11.4 \\
\hline
\end{tabular}

Majority of the respondents $(91.7 \%)$ are married this suggest that most of the respondents are responsible for their families. In addition, the distribution of the respondents according to their household size revealed that $53.1 \%$ and $30.2 \%$ has $9-12$ people and more than 12 people respectively as household members. Most of the respondents $62.5 \%$ practice Islam and $78.1 \%$ has polygamy family. 
The educational qualification(s) of the respondents were presented in Table 1. Few of the respondents (11.5\%) had no formal occupation, $27.1 \%$ had primary school education $40.6 \%$ had secondary school education, $14.5 \%$ had tertiary school education and $6.3 \%$ had vocational education. Most of respondents had one form of education or the other this will help them in their decision making process of adoption or dis adoption of technologies that is best suitable for them. Fadoyin et al.,(2014) also argued that education may not prerequisite to enter into Moringa business, but their productivity could be enhanced by some level of educational attainment.

The distribution of farmers according to their main occupation shows that farming has the highest percentage of $67.7 \%$ and some of the respondents are also engaged in other occupation such as Trading (22.9\%), Civil servant (4.2\%) and Artisan (4.2\%). Majority of the respondents $(78.1 \%)$ has more than five (5) years of farming experience in Moringa oleifera cultivation, $32.3 \%$ has $6-10$ years farming experience while $45.8 \%$ has more than 10 years farming experience. This shows that most of the respondents have experience in moringa oleifera cultivation.

Result from the income realized from Moringa oleifera cultivation per annum showed that the highest percentage, $69.8 \%$ of the respondent realized less than 100,000 , while $21.9 \%$ realized between 100000 150000 and $8.3 \%$ realized the highest income of more than 150,000. This result revealed that most of the farmers from the study area realized income from moringa cultivation.
Adoption and Disadoption of Moringa oleifera:The Result of the adoption and disadoption of Moringa oleifera was presented in Table 2. The result revealed that the respondents have all cultivated Moringa oleifera initially. However, majority of the respondents $63.5 \%$ have stopped cultivating Moringa while $36.5 \%$ continued with the cultivation of moringa oleifera. This shows that the level of disadoption of Moringa in the study area was high.

Table 2: Adoption and disadoption of Moringaoleifera cultivation

\begin{tabular}{lcc}
\hline $\begin{array}{l}\text { Moringa Oleifera } \\
\text { Cultivation Stage }\end{array}$ & Frequency & Percentage \\
\hline Adoption & 96 & 100 \\
Disadoption & 61 & 63.5 \\
Continuance & 35 & 36.5 \\
\hline \multicolumn{2}{c}{ Source: Field Survey, 2018 }
\end{tabular}

Factors contributing to the Dis-adoption of Moringa cultivation: Table 3 shows the factors contributing to disadoption of moringa oleifera among the respondents in the study area. Majority of the respondent $71.9 \%$ indicated that low return on investment on moringa oleifera is a major factor contributing to its disadoption. Low demand of moringa oleifera products such as leaf and seeds $(69.8 \%)$ is another major factor contributing to the disadoption of moringa oleifera cultivation. In addition, low sale of moringa products is also a major factor contributing to the disadopion of moringa oleifera cultivation. Others factors include lack of processing equipment $(54.2 \%)$, lack of marketing channels $(61.5 \%)$ and loss of potency and efficacy of the moringa leaf and seeds $(46.9 \%)$.

\begin{tabular}{lll} 
Table 3: Factors contributing to moringa oleifera dis-adoption among farmers \\
\hline Reasons for disadoption of moringa oleifera & Frequency & Percentage \\
\hline Low demand of moringa oleifera products & 67 & 69.8 \\
Inadequate processing equipment of moringa & 52 & 54.2 \\
Low sales of moringa & 61 & 63.5 \\
Inadequate marketing channels & 59 & 61.5 \\
Over hyped health benefits of moringa products & 45 & 46.9 \\
Low return on investment on moringa & 69 & 71.9 \\
\hline \multicolumn{3}{c}{ Source: Field Survey, } \\
\hline
\end{tabular}

Factors influencing disadoption of Moringa oleifera: Determinants moringa cultivation disadoption are shown on Table 4. The likelihood estimates of the Probitmodel indicated that the chi-square $(\chi 2)$ statistic of 47.54 was highly significant $(\mathrm{P}<0.0001)$ suggesting that the model has a strong explanatory power. The pseudo coefficient of multiple determinations $\left(R^{2}\right)$ shows that 57.64 percent variation in the dependent variable was explained by the included independent variables. This implies that the model showed a good fit to the data. The study revealed that age, membership of farmers' association, non-farm income, and access to extension and involvement of the farmers in other agroforestry practices were significant factors influencing the disadoption of moringa in the study area. However, membership of farmers' association and access to extension services significantly influence the probability of disadoption of moringa cultivation negatively. The coefficient for age, non-farm income and involvement in agroforestry practices were positive and statistically significant at

OKE, DO; ORUMWENSE, LA; OLUGBIRE, OO; ORUMWENSE, LA; OLOBA, OG; AWOFADEJU, JOH; 
$10 \%, 5 \%$ and $1 \%$ respectively. This implies that for every unit increase in age of farmers, there is increase in the likelihood of disadoption of moringa cultivation. This corroborates the findings of Kughuret al., (2017); Adesina and Zinnah, 1993; BonabanaWabbi(1998),affirms that as farmers grow older, there is an increase in risk aversion and a decreased interest in long term investment in the farm. On the other hand, younger farmers are typically less risk-averse and are more willing to try new technologies. Alexander and Van Mellor (2005) also affirms that adoption increase with age for younger farmers as they gain experience and increase their stock of human capital but declines with age for those farmers closer to retirement.

The coefficient for non-farm income was positive and significant. This implies that a naira increase in nonfarm income increases the probability of disadoption of moringa cultivation within the study area. This could be due to the fact that higher non-farm income will reduce their desire to continue the cultivation of moringa. The result corroborates the findings of Holden et al. (2004) who are of the opinion that access to nonfarm income opportunities increased household income but reduced farmer incentives to invest in conservation, leading to rapid land degradation though empirical studies investigating the effect of nonfarm income on technology adoption in Africa have reported mixed findings. Marenya and Barrett (2007); Clay et al. (1998) however, indicated in their results that nonfarm income significantly increased investment in land conservation. Whereas, (Chikwama, 2010) findings show no evidence of contribution of income from rural wage opportunities towards raising households' farm investment.This result is in contrast to the findings that off farm income has been shown to have a positive impact on technology adoption. This is because off-farm income acts as an important strategy for overcoming credit constraints faced by the rural households in many developing countries (Mwangi and Kariuki, 2015; Reardon et al., 2007; Diro and Sam, 2015). Off-farm income is reported to act as a substitute for borrowed capital in rural economies where credit markets are either missing or dysfunctional (Ellis and Freeman, 2004; Diiro, 2013).

\begin{tabular}{lll}
\multicolumn{3}{l}{ Table 4: Factors influencing disadoption of Moringaoleifera cultivation } \\
\hline Variable & Coefficient & $Z_{\text {ratio }}$ \\
\hline Gender & -0.397 & -1.13 \\
Age & 0.122 & $2.46^{* *}$ \\
Household size & -0.212 & -1.50 \\
Membership of farmers' cooperative society & 1.589 & 1.20 \\
Membership of farmers association & -1.966 & $-1.69 *$ \\
Farming experience & -0.081 & -0.26 \\
Non-farm Income & -0.220 & $1.68^{*}$ \\
Income from Moringa. & 0.112 & 0.56 \\
Access to extension & -1.631 & $-1.74 *$ \\
Involvement in other agroforestry practices & 3.835 & $2.97^{* * *}$ \\
Distance of farm to the house & -0.018 & -0.27 \\
Distance of farm to the nearest expressway & -0.059 & -0.69 \\
Constant & -4.247 & -2.12 \\
Chi-square & 47.54 & \\
Prob $>$ chi-square & 0.0000 & \\
Pseudo R-square & 0.5764 \\
Log likelihood & -17.4714 \\
\hline N*P $<0.05$ and $* * * P<0.01=$ Significant at $10 \%, 5 \%$ and $1 \%$ probabilitylevel respectively
\end{tabular}

Another factor that has positive significant influence on disadoption of moringa cultivation is the involvement in other agroforestry practices. This shows that the more the farmers engage in other forms of agroforestry, the greater their likelihood of disadopting moringa cultivation. This shows that the farmers did not stop the practice of agroforestry but only decided to stop moringa cultivation. This may be due to the various factors identified to contribute to disadoption of moringa cultivation. Membership of farmers' association and access to extension services significantly influence the likelihood of disadoption at $10 \%$ significance level. These negative correlation means that farmers who are members of farmers' association and who have access to extension may less likely disadoptmoringa cultivation and may also be more likely to reap the benefit of moringa cultivation. Moreover, membership of association offers farmers access to training, information, inputs, credit and communal agricultural equipment (Sidibé, 2005; Azizi and Zamani, 2009) while access to extension may boost their knowledge and perception about moringa cultivation and thereby discourage disadoption. Lack of access to information about moringaoleifera through extension agents and association is another factor that is likely to influence its disadoption. Access to information reduces the uncertainty about a technology's performance hence may change individual's assessment from purely subjective to objective over time (Caswell et al., 2001; Bonabana-

OKE, DO; ORUMWENSE, LA; OLUGBIRE, OO; ORUMWENSE, LA; OLOBA, OG; AWOFADEJU, JOH; 
Wabbi 2002). It should be noted that lack of access to information though extension agent may also result to dis-adoption of the technology within a farming community where specific technology is limited.This result is also affirmed by Ratchaneewanet al., 2017 in which they are of the opinion that group/association plays an important role in encouraging members to adopt technologies for increased crop production.

Conclusion: The disadoption of Moringa oleifera among farming households in Oyo State was caused mainly as a result of respondents'low return on investment, low demand of moringa and low sale of moringa products. The age of respondents, membership of farmers' association, non-farm income, access to extension and involvement of the farmers in other agroforestry practices were significant factors influencing respondent's disadoption of moringa. However further awareness of health benefit of moringa oleifera will encourage its continuous usage and cultivation.

\section{REFERENCES}

Adesina, A; Zinnah, M.(1993). Technology characteristics, farmers'perceptions and adoption decisions: A Tobit model application in Sierra Leone. Agricultural Economics. vol. 9, issue 4, 297-311.

Animashaun, JO;Ayinde, JO; Fakayode, SB; Muhammad-Lawal, A;Falola, A.; Ifabiyi, JO; ;Toye, AA (2013). An Assessment of the Determinants of Moringa Cultivation among Small-Scale Famers in Kwara State, Nigeria. Food Science and Quality Management. Vol .11 (23), pp. 23-30. ISSN 2224-6088 (Paper) ISSN 2225-0557 (Online).

Alexander, C; Van Mellor, T (2005). Determinants of corn rootworm resistant corn adoption in Indiana. +AgBioForum, 8(4), 197-204.

Azeez, FA.; Nosiru, MO; Clement, NA.; Awodele, DA; Ojo, D;Arabomen, O(2013). Importance of Moringaoleifera tree to human livelihood: a case study of Isokan local government area in Osun State. Elixir Agriculture 55:12959-12963.

Azizi KT; Zamani, GH(2009). Farmer participation in irrigation management: The case of Doroodzan Dam Irrigation Network, Iran. Agric. Water Manag., 96, 859-865.

Bonabana-Wabbi, J (1998). Assessing factors affecting adoption of agricultural technologies: the case of integrated pest management (IPM) in
Kumi District, Eastern Uganda. M.Sc. thesis, Agricultural and Applied Economics Department Virginia Technology Blacksburg, Virginia.

Caswell, M; Fuglie, KO; Ingram, C; Jans, S; Kascak, C (2001). Adoption of Agricultural Production Practices: Lessons learned from the US Department of Agriculture Area studies project. E.R.S: USDA. Issue No. 2364. p.17.

Chikwama, C (2010). "Rural Off-farm Employment and Farm Investment: An Analytical Framework and Evidence from Zimbabwe". African Journal of Agriculturaland Resources Economics, Vol. 4, No 1: 1-22.

Clay, D., Reardon, T;Kangasniemi, J (1998). "Sustainable Intensification in the Highland Tropics: Rwandan Farmers' Investment in Land Conservation and Soil Fertility". Economic Development and Cultural Change. 46 (2). 351377.

Diiro, G (2013). Impact of Off-farm Income on Technology Adoption Intensity and Productivity: Evidence from Rural Maize Farmers in Uganda. International Food Policy Research Institute, Working Paper 11

Diiro, GM; Sam, AG (2015). Agricultural Technology Adoption and Nonfarm Earnings in Uganda: A Semi Parametric Analysis. The Journal of Developing Areas. Vol. 49, No. 2, pp. 147-162.

Dandedjrohoun, L;Diagne, A; Biaou, G; N'cho, $\mathrm{S}$;Midingoyi, S (2012). Determinants of diffusion and adoption of improved technology for rice parboiling in Benin. Review of Agricultural and Environmental Studies, 93 (2), 171-191.

Dontsopnguezet, PM; Diagne, A;Okoruwa, VO.(2010). Estimation of actual and potential adoption rates and Determinants of improved rice variety among rice Farmers in Nigeria: the case of NERICAS, Contributed Paper presented at the Joint 3rd African Association of Agricultural Economists (AAAE) and 48th Agricultural Economists Association of South Africa (AEASA) Conference, Cape Town, South Africa, September 19-23, 2010.

Ellis, F; Freeman, H (2004). "Rural Livelihoods and Poverty Reduction Strategies in Four African Countries." Journal of Development Studies. 40(4):1-30 
Fadoyin, AS; Oyewole, SO;Ayanrinde, FA; Baba, GA.; Erhabor, TA. (2014). Socio-economic factors influencing adoption of Moringaoleifera water purification by farmers in Kaduna state, Nigeria. Inter. Let. Nat. Sci. 20. 85-90, 2014

Goodwin, B; Mishra, A (2002). Farming Efficiency and the Determinants of Multiple Job Holding by Farm Operators. American Journal of Agricultural Economics. 86 (3): 722-729.

Gujarati, D (2004). Basic Econometrics, Fourth Edition, McGraw-Hill.

Holden, S; Shiferaw, B; Pender, J (2004). Nonfarm Income, Household Welfare, and Sustainable Land Management in a Less-favored Area in the Ethiopian Highlands. Food Policy. 29. 369-392.

Kughur, PG; Okeme, S;Katikpo, G (2017). Assessment of Adoption of Integrated Pest Management Practices among Cowpea Farmers. Production, Agriculture and Technology. 13 (2): 27-39 ISSN: 0794-5213. Online copy available at www.patnsukjournal.net/currentissue. Publication of Nasarawa State University.

Lagar, LM; Pandey S (1999). "Adoption of Soil Conservation: The Case of the Philippine uplands": Agricultural Economics.21 (3). 241256.
Marenya, PP; Barrett, CB (2007). Household-Level Determinants of Adoption of Improved Natural Resource Management Practices among Smallholder farmers in Western Kenya. Food Policy. 32. 515-536.

Mwangi, M; Kariuki, S (2015). Factors Determining Adoption of New Agricultural Technology by Smallholder Farmers in Developing Countries. Journal of Economics and Sustainable Development.6. (5). 208-216.

Ratchaneewan, C; Nophea, S; Issei, A(2017). Influencing Fctors of the Adoption of Agricultural Irrigation Technologies and the Economic Returns: A Case Study in Chaiyaphum Province, Thailand. Sustainability. 9 (1524)pp. 1-16.

Reardon, T; Stamoulis, K;Pingali, P (2007). "Rural Nonfarm Employment in Developing Countries in an era of Globalization." Agricultural Economics. 37:173-183

Sidibé, A (2005). Farm-level adoption of soil and water conservation techniques in northern Burkina Faso. Agric. Water Manag. 71, 211224.

Torimiro, DO; Oluborod AA (2006). Exploring socioeconomic correlates of production needs for enhancing food security through farm youth in southwest Nigeria. Pakistan J. Engineer. Appl. Sci. 2: 248-255. 